\title{
Problem Based Civics Learning for Empowering Young Citizens Participation
}

\author{
Mutiara Nurmanita ${ }^{1}$, Samsuri $^{2}$ \\ Department of Pancasila and Citizenship Education Study Program \\ Yogyakarta State University \\ Yogyakarta, Indonesia \\ ${ }^{1}$ mutiara.nurmanita2016@student.uny.ac.id, 22samsuri@uny.ac.id
}

\begin{abstract}
Writing aims to explain and analyze the application of problem based learning model against the formation of the young citizen participatory. This is effected by some research study conducted by some experts associated with the growing participation rates declined by $45 \%$, the opinions of the students just heard by only $33 \%$ of teachers and learners to rights talked related social issues, politics, religion, economics, education, and defense and security. Methods used quasi experimental design of posttest only with a non-equivalent group design. The population in the research of Class VII with the subject Class VII E as class experiments and VII $B$ as the class of the control. The results showed that there is a difference in average for class experiments of 90.80 and a control class of 83.07. That means learning that using problem based learning model is more significant in matter of cooperation in various areas of life. The results of calculations on a class experiment shows that the model of problem based learning effect on the formation of participant skills $0.000 \leq 0.05$ or thitung $\geq t$ tabel is $\mathbf{1 . 6 9 9 1 3} \geq \mathbf{5 8 . 6 2 8}$ meaning that Ho was rejected. The application of problem based learning model was influential in the formation of young citizens through participatory steps as follows. Clarification of issues, discussion of the issue, troubleshoot and resolve the issue, presenting solutions, and conducting evaluation of learners.
\end{abstract}

Keywords-participation; problem based learning; young citizens

\section{INTRODUCTION}

Democratic Government should provide freedom and discretion to citizens in a fringe opinions, arguments, and commented on the problems of governance in the case. Citizens have a role to success in democratic Government. The level of participation of citizens are often categorized as political participation [1]. Political activities also made a polemic on the existence of the Government. However, often differences of opinion occurred made the young citizen participation activities tend to increase trends such as the religious and political extremism to flourish so that made the road to erode democracy [2].

Democracy with regard to civic education. But in this case, there is a disparity in citizenship education such as the level of knowledge and skills, learning path only as citizenship education, no special guarantees if the concept of citizenship in accordance with the intended learning [3]. Problems in citizenship education in Indonesia is the paradigm of citizenship education is based that the residents comply not just education and actualization of citizenship does not focus on the knowledge of the institution or the Government so that the preparation for the young citizens involved in the activities of the Government are reasonable if not very considered and not taken into account [4].

Problems that occur due to the lack of involvement of young citizens in the United Kingdom such as decreased due to less actualizing [5]. In addition, based on the results of research conducted by Benedicto \& Blasco that the highest political interest found in Germany $(50.5 \%)$, Italy (43\%), and Australia (42\%) while the lowest levels were found in the United Kingdom (29.6\%), Estonia (29.3\%) and Slovakia (27.8\%) [6]. It affects the level of literacy toward social and political problems.

In a research study conducted by Kus that the level of participation of students in Turkey are classified low [7]. It can be noted that learners are only given the opportunity to explain the learning acquired around $51 \%$, students are only allowed to take source readings around $48 \%$, and the opinions of the students just heard by teacher of $45 \%$. Sometimes students do not have the right to speak with a percentage of $33 \%$.

The next level of trust young Indonesia citizens against the political elite led to the decrease in the youth participation rate against the decision making process. Young citizens is also often viewed as people who do not know and do not understand how to solve a problem of political as well as social economy [8]. The need for efforts that can increase the participation of young citizens by renewing formal methods that tend to cause the level of participation of the young citizen downhill [3].

The model can increase the participation of young citizens is through problem based learning so that learners are active and involved in the activities of the project so that it can form the attitude of participation [9]. This is very effective for learning helps learners to be able to conduct research in person to engage in problem solving [10].

The importance of the problem based learning model as an effective learning for teachers and learners in developing social studies such as social issues, the skills and the values of democracy to improve the knowledge, communication skills, that can develop to its full potential [11]. In addition, the 
learning problem based learning can improve understanding of learners in order to be able to cooperate with others [12]. So the authors keen to multiply further and analyse about the application of problem based learning model for the formation of the young citizen participatory.

\section{LITERATURE REVIEW}

\section{A. Problem Based Learning}

Learning problem based learning focuses on problems that are all around. In addition students will work collaboratively so that students will understand what has been done by way of formulating the problem and analyze the appropriate facts [10]. This essentially makes the learning problems as a focus to resolve the problem in accordance with real-life data and facts. The retrieval of data can be done by doing a search process information from a variety of sources both from electronic media as well as nonelektronik. The sources for later analyzed together to produce a solution.

Steps in problem based learnings sbeagai here. First, the orientation of the students on the issue. Second, set the learners in learning. Third, the identification of the problem. Fourth, initiate an investigation. Fifth, formulating the problem. Sixth, develop a hypothesis. Seventh, the discussion to solve problems. Eighth, analyze and evaluate issues [12]. In this case, the researcher summarizes these steps; clarification, discussion, problem solving and resolving problems, the presentation of the solution, and evaluation.

\section{B. Participation}

Every citizen should have some competence skills include citizenship citizenship consists of intellectual skills and participation skills. One of the skills that need to be there i.e. skills partispasi. Participation with regard to the concept of democracy because the delivery process includes consultation, decision making even exert influence against a policy [13]. However, the level of participation of the young citizen downhill in dratis due to a lack of participation in the activities of social blend [14].

Factors that influence the young citizens to be able to participate because there needs to be political values formation as a political culture that exists in the community. For example the voting activities in school as OSIS [3]. These activities can be done outside school hours so that the learning process is not interrupted. Even can also be linked to 64ba learning model in accordance with the process of the investigation and the decision making process.

\section{Young Citizen}

Young citizen as a component of the community who have a role in the progress of a country because young citizens considered the subject of the success of a country in decisionmaking [3]. In addition, young citizens not only have the right passive is responsible for becoming active citizens by providing and engage in political participation which is part of the dimensions citizenship [15].
Citizenship of young citizens in the 21st century is indispensable in order to have some competence who not only develop knowledge but will also understand and troubleshoot globally such as political, social, cultural, economic, and environment [16]. Competence-competence that should be owned by young citizens in the 21 st century in addition to the development of knowledge but also of technological literacy and able to intelligently make use of technology and participatory.

\section{METHOD}

These studies use quantitative methods are categorized in artificial experiments. The design in the research was the posttest only with non-equivalent group design with a learning problem based learning. The design of the research can be seen in table 1.

TABLE I. DESIGN RESEARCH

\begin{tabular}{|c|c|c|}
\hline Class & Treatment & Posttest \\
\hline Experiment & $\mathrm{X}$ & $\mathrm{Y}$ \\
\hline Control & - & $\mathrm{Y}$ \\
\hline
\end{tabular}

Based on table 1, it can be noted that the design of the research is the first group that is given the treatment of problem based learning as classroom experiments while the second group was not given preferential treatment. Then the two groups will be given posstest to see the difference in the two groups. The population in the study Class VII with a sample of 60, Class VII E 30-classroom learners to experiment and classes VII B 30-classroom learners to control SMP 2 Bantul. Variables used is problem based learning and variables are bound is participatory. The calculation is done with its homogeneity and normality test. Then conducted data analysis with test engineering-t.

\section{RESULT AND DISCUSSION}

The need for improvements in the civic education study to relate the important issues. First, democracy and citizenship, economic, social, and political need to be done on the democracies tend to be new and stable. Second, the school should play a role in civic education, especially in the field of political participation. Third, there is increasing support from the various components of the school, family, and community. Fourth, the need for an agreement on the approach to learning that build relatively flimsy participation of learners [2]. Those issues need to be incorporated into the curriculum for the subjects civics and Citizenship because as an attempt to realize the vision and mission of the nation and the State of Indonesia, namely citizens who are intelligent, character, capable of participating. One of the efforts carried out by the appropriate learning model with the purpose to be achieved. One of them with project-based learning.

Research using a measurement tool to see the difference of class VII E using problem based learning model and VII B do not use it with partisipastif on a basic competent 3.5 Analyse the forms of cooperation in different areas of life. Analysis of the value obtained from the posttest trial $t$ form to know the 
differences result from the application of a participatory attitude problem based learning. Based on the results of research to the average skill of the participatory class experiments have on average higher than the class of the control. Average acquisition experiment class VII E of 90.80 while on class control classes VII B amounted to 83.07. The results indicate that there is a difference in the analysis of the average for the two groups. On the aspect of organizing others to experimental class of 82.5 while on class control of 79.66 . On building a mutual agreement that results obtained for experimental class of 73.61 while on class control retrieved results of 69.44. The next aspect to listen to various opinions obtained the result that for a class experiment 95 while on class control of 83.54. In addition, the acquisition results in responding to the various issues the public aspect of the class of experiment of 81.11 and of control of 65 .

Tally the results of the two groups to komptensi the base 3.5 analyse the forms of cooperation in different fields of life class VII can be analyzed that there is a difference in the usage model of problem based learning and not given the treatment. These data indicate that the class wants class VII E has a tally of results with the calculation of test-t found in table 2 .

TABLE II. THE RESUlTS OF THE CALCULATION TO THE INFLUENCE OF LEARNING PROBLEM BASED LEARNING FOR PARTICIPATORY ATTITUDE FORMATION

\begin{tabular}{|l|l|l|l|l|}
\hline \multicolumn{1}{|c|}{ Variable } & \multicolumn{1}{|c|}{ Test-t } & \multicolumn{1}{|c|}{ df } & \multicolumn{1}{|c|}{ Sig } & $\begin{array}{c}\text { The results } \\
\text { of the } \\
\text { decision }\end{array}$ \\
\hline $\begin{array}{l}\text { Participatory } \\
\text { skills }\end{array}$ & 58,628 & 29 & 0,000 & Ho= rejected \\
\hline
\end{tabular}

Based on table 1, it can be noted that the results of the calculation of test-t for class experiments with df of 29 to significant extent is 0.000 . Next thitung results of 58.628. The decisions taken if significant extent $0.000 \leq 0.05$ or thitung $\geq$ ttabel. So it can be inferred that $58.628 \geq 1.69913$ or $0.000 \leq$ 0.05 . This means that there is an influence of the learning problem based learning model for the establishment of a participatory attitude of learners Class VII class experiments with $\mathrm{E}$ or decision that Ho is rejected.

Problem-based learning model is a model of learning which can make students active and participate. In line with the opinion of the Ribeiro that the problem based learning is learning to develop their knowledge and skills [17]. The use of step-step problem based learning expressed by Zwaal \& Otting, which became the reference of researchers to apply the model in Class VII E which includes, as follows [18]. First, learners are divided based on each field religious, social, political, economic, education, and defense and security. Then the learners do the clarification to the problems encountered from any cooperation in accordance with the group. Second, each group discuss the issue. For example in the field of religion, the Group solve the problem of Islamic and Christian conflict in Papua which many cause casualties. Here make up some of the questions include: what is the conflict? Why is there a religious conflict in Papua? How do I resolve the conflict?
In addition, the group will resolve the issue against these questions together. Third, each group to solve and resolve the problem with finding some good sources of information from electronic media as well as nonelektronik. Fourth, information that has been retrieved is then distributed to the learner group. Fifth, each group will present a solution to the problems that have been summarized earlier. Presentation of solutions to answer the questions that have been made by various sources. The presentation of the solution is done with a presentation in front of the class. Furthermore, the sixth that is doing the evaluation by providing a conclusion against the learning that has been implemented.

Based on the results of research conducted on the experimental and the control class can be analyzed that the learning that using problem based learning model is more influential than the control class that is of $0.000 \leq 0.05$ or $58.628 \geq 1.69913$ so be aware that the model of problem based learning for the formation of the young citizen participatory. The learning steps using problem based learning model can form participation due to problem based learning can involve learners in the process of solving problems [19].

The success of problem-based learning conducted by researchers Kokotsaki, Menzies \& Wiggins is due to the ability of teachers in designing learning, motivating learners to be active in making moral support with tasks given by the teacher [20]. The role of all parties both from teachers, parents or society in the process of completion of the project carried out by learners is very needed by not eliminating the way or the ethics of the learners in the process of investigation. Including learners together in groups affect the interview against the speaker that will be asked are related to the selected problem is corruption.

Next a results of research conducted by Edwards that problem-based learning in schools need to be made a special program to create young citizens to active, and participated by involving component communities as non-governmental organizations in decision-making [21]. Young citizens able to overcome and resolve the various social and cultural issues as well as the provision of a special room for discussion for young citizens. Inseparable from the goal to make young citizens who are active and are able to participate with not neglecting knowledge against the problems resolved.

Young citizens is in school namely learners which has the role to get involved in the decision-making process with a democratic attitude, skilled, and responsible for the completion of the project provided by the teacher [8]. How to increase the participation of learners with problem-based learning is to make learners as subjects of learning to perform various tasks with active and participatory experience. In addition, learners do the decision making process with deliberation, compromise, speaking in public, expressing opinions, work in groups, and assimilate the opinions of others [5]. The students not only able to perform the role of young citizens by learning actively towards project-based learning model is done by the teachers, but also practice against the experience found when directly involved in the learning. 


\section{CONCLUSION}

Young citizens as part of the community have a very precise role in the resolution of any problems that occur in the Government. Young citizen is often not considered in the decision-making process. It is based on research carried out by some experts who say that the level of participation of young citizens in Indonesia is still categorized decreased due to a few things. As the understanding of the concept of educational learning only as a knowledge when it is not in accordance with the ideals of a nation that is supposed to be a science that is obtained can be actualization in real life.

The embodiment of the actualization of can be done with the model of learning in school is through innovative learning model and the power of creativity to support learners. One of them with a model of the problem based learning through multiple step is clarification, discussion, problem solving and resolving problems, the presentation of the solution, and evaluation. Thus it can be concluded that the use of the model of problem based learning effect on the level of participation of young citizens on the basis of the analysis process 0.000 where $\leq 0.05$ or $58.628 \geq 1.69913$. This means that there is significant influence model of problem based learning towards the formation of the young citizen participatory.

\section{REFERENCES}

[1] J. Erman and E. Amna "Political participation and civic engagement towards a new typology," Human affairs, vol. 22, pp. 283-300, 2012.

[2] T. Solhaung, "Trends and dilemmas in citizenship education," Journal of humanities and social science education, vol. 1, pp. 180-200, 2013.

[3] A.I. Pontes, M. Henn, and M.D. Griffths, Towards a conceptualization of young people political engagement: a qualitative focus gorup study. UK: Department of politics and international relations, 2017.

[4] B. Hoskins, M. Saisana, and C.M.H. Villalba, "Civic competence of youth in Europe: measuring cross national variation through the creation of a composite indicator," Indic res, vol. 123, pp. 431-457, 2015.

[5] A. Keating and J.G. Janmmat, Education through citizenship at school: do scool activities have a lasting impact on youtu political engagement? London: parliamentary affairs advance access, 2015.
[6] J. Benedicto and A.L. Blasco, Young people and political participation: european research. Young people's studies magazine, 2017.

[7] Z. Kus, "Participation status of primary school students," Social and behavioral sciences, vol. 177, pp. 100-196, 2015.

[8] E. Anderson, "Young people's political participation: a public pedagogy challenge at the municipal level," Young, vol. 20, no. 2, pp. 179-195, 2017.

[9] Y.C.G. Mali, "Project-based learning in indonesian efl classroom: from theory to practice," Indonesian journal of english education, vol. 3, no. 1, pp. 89-105, 2016

[10] E. Cindy, "Problem-based learning: what and how do students learn?" Educational psychology review, vol. 16, no. 3, 2004.

[11] I. Ilter, A study on the efficacy of project-based learning approach on social studies education: conceptual achievement and academic motivation. Turkey: University of Bayburt, 2014.

[12] Darmawati, P. Bundu, and D. Manda, "Problem based learning model development of civic education to improve the motivation and learning outcomes," International journal of enviromental \& science education, vol. 12, no 9, pp. 2049-2061, 2017.

[13] A. Michels and L.D. Graaf, "Examining citizen participation: local participatory policy making and democracy," Local government studies, vol. 36, no. 4, pp. 477- 491, 2010.

[14] H. Catt, Chidren and young people as citizens: participation provision and protecttion. Paper. 6 th child and familiy policy conference, University of Otago, 2005.

[15] H. Helve, "Re-thinking youth and citizenship, value groups and citizen types of young finns," Italian journal of sociology of education, vol. 7, no. 1, pp. 32-66, 2015.

[16] J. Penner and J. Sanderse, The role of economic citizenship education in advancing global citizenship. Policy \& practice: a development education review, 2012

[17] L.R.C. Ribeiro, "The pros and cons of problem-based learning from the teacher's standpoint," Journal of university teaching \& learning practice, vol. 4, no. 8, 2011.

[18] W. Zwaal and H. Otting, "The impact of concept mapping on the process of problem-based learning," Interdisciplinary journal of problem-based learning, vol. 1, no. 6, 2012.

[19] S.M. Butler, "The process of problem-based learning: a literature review," Journal of education and training studies, vol. 13, no. 9, 2010.

[20] D. Kokotaski, V. Menzies, and A. Wiggins, "Project-based learning:a review of the literature," Improving schools, pp. 1-11, 2016.

[21] K. Edwards, "Young citizens and political participation in a digital society," Communication \& society, vol. 18, no. 12, pp. 1470-1472, 2015 . 